\title{
An Analysis of the Synergy Degree of Insurance Innovation and Financial Development in China
}

\author{
Ping $\mathrm{Yu}$ \\ School of Economics \\ Wuhan University of Technology \\ Wuhan, China \\ e-mail: toyuping@126.com
}

\author{
Peiran Guo \\ School of Economics \\ Wuhan University of Technology \\ Wuhan, China \\ e-mail: perringpr@gmail.com
}

\begin{abstract}
The objective of this paper was to figure out the synergetic relationship between two subsystems of the financial system, to measure the synergy degree of them, and to propose suggestions used to develop both insurance innovation and financial development. Synergetic theory was used in this paper to analyze the relationship between insurance innovation and financial development in China. The author built a model to measure the degree of order of the two subsystems. Different indexes were introduced to explain the order performance. And another model, which was based on the former model, was built to measure the synergy degree of the subsystems. The empirical analysis shows that China's financial development is in a steady upward track, but the insurance innovation faces a tough situation. The degree of order of insurance innovation subsystem has been decreasing since 2009. And the low synergy degree of two subsystems indicates that there is a disharmony development relationship between them.
\end{abstract}

Keywords-insurance innovation; financial development; synergy degree; degree of order; synergtic development

\section{INTRODUCTION}

As an important part of modern service industry, the insurance industry has become one of the fastest growing sectors of the national economy. The progress of insurance innovation promotes the financial development, while the promotion of financial development reacts on the level of insurance innovation[1]. Therefore, insurance innovation and financial development are two interrelated subsystems. There is an interactive effect between them. The synergy degree of them is the foundation of national economic development[2].

The relationship between insurance innovation and financial development was first studied in last 90s. There was a positive correlation between development of insurance and financial development[3]. Insurance industry growth had something to do with economic growth, but the causal relationships between them were different from nation to nation in OECD countries[4]. In the demand-following case, the development of finance increased the demand for new insurance service, resulting in boom of insurance innovation; in the supply-leading case, insurance companies were devoted to expand business scales and compete for market share, which contributed to innovation of insurance products and service[5]. Another studies showed that the relationship between insurance innovation and financial development was restricted by many factors, conditions of promoting or hindering mutually might appear in different situations[6][7]. The study under financial synergy perspective indicated that there was an obvious competitive relationship between the whole insurance (as well as life insurance) industry and banking industry. But there wasn't a dominate party in the competitive and complementary relationship between possession insurance industry and banking industry[8].

The study in IT industry in China built models to measure the degree of order and coordinating level of the entire system consisted of four IT subsystems[9]. Synergy degree model was set in the study of the relationship between technology innovation and energy efficiency, and explained the synergy level of the subsystems of high-tech industry in China[10].

In summary, the mutual close association between insurance innovation and financial development had been widely recognized by academia, but the situation of evolution trends deviating, inconsistent development paces and disordered development paths between them had restricted the development of insurance and finance, even been the barrier of national economic growth.

\section{SYNERGY MODEL AND EMPIRICAL ANALYSIS OF INSURANCE INNOVATION AND FINANCIAL DEVELOPMENT}

\section{A. Degree of order Model of Subsystem}

Let the complex system $\mathrm{S}$ consist of insurance innovation subsystem and financial development subsystem $S_{-} j, j \in[1,2]$.The statue and structure of subsystem $\mathrm{Sj}(\mathrm{Sj} 1, \mathrm{Sj} 2, \cdots \cdots, \mathrm{Sjm})$ is determined by order parameters. Let the order parameters of insurance innovation and financial development $e_{j}=\left(e_{j 1}, e_{j 2}, \ldots \ldots e_{j m}\right), m \geq 1, \quad \beta_{j i} \leq$ $\mathrm{e}_{\mathrm{ji}} \leq \alpha_{\mathrm{ji}}$, $\mathrm{i} \in[1, \mathrm{~m}]$. The degree of order of subsystem is defined as:

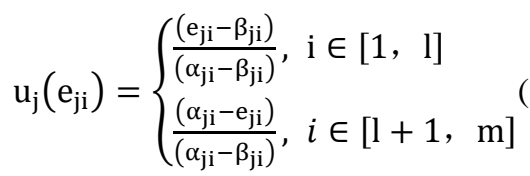


a $\mathrm{ji}$ is the maximum value of $\mathrm{i}$ index, $\mathrm{j}$ system. $\beta \mathrm{ji}$ is the minimum value of $\mathrm{i}$ index, $\mathrm{j}$ system. The total contribution, which is made from order parameter eji to the degree of order of $\mathrm{Sj}$, can be measured by accumulating ui (eji) . Geometric mean method is used to describe the subsystem's function of degree of order in this paper.

$$
u_{j}\left(e_{j}\right)=\sqrt[m]{\prod_{i=1}^{m} u_{j}\left(e_{j i}\right)} j=1,2
$$

\section{B. Synergy degree Model of Subsystems}

Let uj0 (ej) equal the degree of order of subsystem's order parameter at initial time, uj1 (ej) equal the degree of order of subsystem's order parameter at a given time in the developing process of complex system. The synergy degree of subsystems can be defined as:

$$
\begin{gathered}
\operatorname{syn}=\eta \sum_{j=1}^{m} \delta_{j}\left|\mu_{j}{ }^{1}\left(e_{j}\right)-\mu_{j}^{0}\left(e_{j}\right)\right|(3) \\
\eta=\frac{\min \left[\mu_{j}{ }^{1}\left(e_{j}\right)-\mu_{j}{ }^{0}\left(e_{j}\right) \neq 0\right]}{\left|\min \left[\mu_{j}{ }^{1}\left(e_{j}\right)-\mu_{j}{ }^{0}\left(e_{j}\right) \neq 0\right]\right|} \\
j=1,2, \ldots, m, \delta_{j} \geq 0, \sum_{j=1}^{n} \delta_{j}=1
\end{gathered}
$$

\section{Empirical analysis of the synergic evolution of} insurance innovation and financial development

Choosing the index system of insurance innovation and financial development subsystem according to the rationality and feasibility, comprehensiveness and comparability principle. The evaluation index system of insurance innovation is in Table I and the evaluation index

\begin{tabular}{|c|c|c|}
\hline Category & Index & Meaning \\
\hline Scale & $\mathrm{e}_{11}=$ Premium $/ \mathrm{GDP}$ & Insurance scale \\
\hline Risk & $\begin{array}{l}\mathrm{e}_{12}=\text { Compensation and } \\
\text { benefit/Premium }\end{array}$ & $\begin{array}{c}\text { Level of risk } \\
\text { control } \\
\text { innovation } \\
\end{array}$ \\
\hline \multirow{2}{*}{$\begin{array}{l}\text { Structure of } \\
\text { insurance } \\
\text { asset }\end{array}$} & $\begin{array}{c}\mathrm{e}_{13}=\text { Asset of reinsurance } \\
\text { company/Asset of insurance } \\
\text { industry }\end{array}$ & $\begin{array}{c}\text { Level of } \\
\text { insurance } \\
\text { innovation } \\
\end{array}$ \\
\hline & $\begin{array}{c}\mathrm{e}_{14}=\text { Asset of foreign insurance } \\
\text { company/Asset of insurance } \\
\text { industry }\end{array}$ & $\begin{array}{c}\text { Level of } \\
\text { insurance } \\
\text { market opening }\end{array}$ \\
\hline \multirow{4}{*}{$\begin{array}{l}\text { Utilization } \\
\text { of } \\
\text { insurance } \\
\text { asset }\end{array}$} & $\begin{array}{l}\mathrm{e}_{15}=\text { securities investment fund of } \\
\text { insurance fund / Insurance fund } \\
\text { balance }\end{array}$ & \multirow{2}{*}{$\begin{array}{c}\text { Level of } \\
\text { innovative } \\
\text { utilization of } \\
\text { insurance asset }\end{array}$} \\
\hline & $\begin{array}{l}\mathrm{e}_{16}=\text { corporate-bond of insurance } \\
\text { fund /Insurance fund balance }\end{array}$ & \\
\hline & $\begin{array}{l}\mathrm{e}_{17}=\text { bank deposits of insurance } \\
\text { fund /Insurance fund balance }\end{array}$ & \multirow{2}{*}{$\begin{array}{c}\text { Level of } \\
\text { traditional } \\
\text { utilization of } \\
\text { insurance asset }\end{array}$} \\
\hline & $\begin{array}{l}\mathrm{e}_{18}=\text { national debt of insurance } \\
\text { fund /Insurance fund balance }\end{array}$ & \\
\hline
\end{tabular}
system of financial development is in Table II.

TABLE I. EVALUATION INDEX SYSTEM OF INSURANCE INNOVATION

\begin{tabular}{|c|c|c|}
\hline Category & Index & Meaning \\
\hline \multirow{2}{*}{$\begin{array}{c}\text { Financial } \\
\text { development }\end{array}$} & $\mathrm{e} 21=\mathrm{FIR}=(\mathrm{M} 2+\mathrm{L}+\mathrm{S}) / \mathrm{GDP}$ & $\begin{array}{c}\text { Finance structure and } \\
\text { development }\end{array}$ \\
\hline & $\mathrm{e} 22=\mathrm{M} 2 / \mathrm{GDP}$ & $\begin{array}{c}\text { Monetary degree of } \\
\text { economy }\end{array}$ \\
\hline \multirow{2}{*}{$\begin{array}{l}\text { Technology } \\
\text { capital }\end{array}$} & $\mathrm{e} 23=\mathrm{R} \& \mathrm{D}$ of finance & $\begin{array}{c}\text { Level of technology } \\
\text { capital }\end{array}$ \\
\hline & $\begin{array}{c}\text { e24= number of R\&D staff/ } \\
\text { number of financial staff }\end{array}$ & $\begin{array}{l}\text { Level of technological } \\
\text { human resource }\end{array}$ \\
\hline \multirow{3}{*}{$\begin{array}{l}\text { Financial } \\
\text { instruments }\end{array}$} & e25= Stock turnover & $\begin{array}{c}\text { performance of stock } \\
\text { market }\end{array}$ \\
\hline & $\begin{aligned} \mathrm{e} 26= & \text { corporate-bond } \\
& \text { issuance }\end{aligned}$ & $\begin{array}{c}\text { Performance of } \\
\text { enterprise financing } \\
\text { platform }\end{array}$ \\
\hline & $\begin{array}{c}\text { e27= total volume of } \\
\text { futures }\end{array}$ & $\begin{array}{l}\text { Performance of } \\
\text { futures market }\end{array}$ \\
\hline
\end{tabular}

TABLE II. EVALUATION INDEX SYSTEM OF FINANCIAL DEVELOPMENT

The values of order parameters of the insurance innovation subsystem and the financial development subsystem are gathered and classified from STATISTICAL YEARBOOK OF CHINA and FINANCIAL STATISTICAL YEARBOOK OF CHINA. The range of the data is from 2005-2012 and listed in Table III and Table IV.

TABLE III. VALUES OF ORDER PARAMETERS OF INSURANCE INNOVATION SUBSYSTEM

\begin{tabular}{|c|c|c|c|c|c|c|c|c|}
\hline $\begin{array}{c}\text { Yea } \\
\mathbf{r}\end{array}$ & $\mathbf{e}_{\mathbf{1 1}}$ & $\mathbf{e}_{\mathbf{1 2}}$ & $\mathbf{e}_{\mathbf{1 3}}$ & $\mathbf{e}_{\mathbf{1 4}}$ & $\mathbf{e}_{\mathbf{1 5}}$ & $\mathbf{e}_{\mathbf{1 6}}$ & $\mathbf{e}_{\mathbf{1 7}}$ & $\mathbf{e}_{\mathbf{1 8}}$ \\
\hline 200 & 0.02 & 0.23 & 0.01 & 0.04 & 0.07 & 0.08 & 0.36 & 0.25 \\
5 & 69 & 05 & 9 & 4 & 86 & 55 & 65 & 48 \\
\hline 200 & 0.02 & 0.25 & 0.01 & 0.04 & 0.05 & 0.11 & 0.33 & 0.20 \\
6 & 61 & 50 & 6 & 4 & 13 & 93 & 67 & 51 \\
\hline 200 & 0.02 & 0.32 & 0.03 & 0.04 & 0.09 & 0.10 & 0.24 & 0.14 \\
7 & 64 & 19 & 0 & 3 & 45 & 51 & 41 & 85 \\
\hline 200 & 0.03 & 0.30 & 0.03 & 0.04 & 0.05 & 0.15 & 0.26 & 0.13 \\
8 & 10 & 37 & 0 & 6 & 39 & 05 & 47 & 77 \\
\hline 200 & 0.03 & 0.28 & 0.02 & 0.05 & 0.07 & 0.16 & 0.28 & 0.10 \\
9 & 27 & 06 & 9 & 1 & 37 & 23 & 11 & 83 \\
\hline 201 & 0.03 & 0.22 & 0.02 & 0.05 & 0.05 & 0.17 & 0.30 & 0.10 \\
0 & 63 & 03 & 3 & 2 & 69 & 23 & 21 & 46 \\
\hline 201 & 0.03 & 0.27 & 0.02 & 0.05 & 0.05 & 0.15 & 0.32 & 0.08 \\
1 & 06 & 40 & 6 & 0 & 27 & 86 & 06 & 59 \\
\hline 201 & 0.03 & 0.30 & 0.02 & 0.04 & 0.05 & 0.15 & 0.34 & 0.07 \\
2 & 00 & 45 & 5 & 7 & 29 & 90 & 21 & 00 \\
\hline
\end{tabular}


TABLE IV. VALUES OF ORDER PARAMETERS OF FINANCIAL DEVELOPMENT SUBSYSTEM

\begin{tabular}{|c|c|c|c|c|c|c|c|}
\hline $\begin{array}{c}\text { Yea } \\
\mathbf{r}\end{array}$ & $\mathbf{e}_{\mathbf{2 1}}$ & $\mathbf{e}_{\mathbf{2 2}}$ & $\mathbf{e}_{\mathbf{2 3}}$ & $\mathbf{e}_{\mathbf{2 4}}$ & $\mathbf{e}_{\mathbf{2 5}}$ & $\mathbf{e}_{\mathbf{2 6}}$ & $\mathbf{e}_{\mathbf{2 7}}$ \\
\hline $\begin{array}{c}200 \\
5\end{array}$ & $\begin{array}{c}1.53 \\
81\end{array}$ & $\begin{array}{c}1.61 \\
54\end{array}$ & 487 & $\begin{array}{c}4 \\
86\end{array}$ & $\begin{array}{c}6,623.7 \\
3\end{array}$ & $\begin{array}{c}2,046.5 \\
0\end{array}$ & $\begin{array}{c}32,287.4 \\
1\end{array}$ \\
\hline $\begin{array}{c}200 \\
6\end{array}$ & $\begin{array}{c}3.08 \\
63\end{array}$ & $\begin{array}{c}1.59 \\
76\end{array}$ & 278 & $\begin{array}{c}0.41 \\
12\end{array}$ & $\begin{array}{c}16,145 . \\
23\end{array}$ & $\begin{array}{c}3,938.3 \\
0\end{array}$ & $\begin{array}{c}44,950.8 \\
2\end{array}$ \\
\hline $\begin{array}{c}200 \\
7\end{array}$ & 4.03 & 1.51 & \multirow{2}{*}{404} & $\begin{array}{c}0.40 \\
69\end{array}$ & $\begin{array}{c}36,403 . \\
77\end{array}$ & $\begin{array}{c}5,058.5 \\
0\end{array}$ & $\begin{array}{c}72,846.0 \\
8\end{array}$ \\
\hline 200 & 3.03 & 1.51 & 536 & 0.41 & $24,131$. & $8,435.4$ & $136,395$. \\
8 & 64 & 3 & & 06 & 39 & 0 & 97 \\
\hline 200 & 4.04 & 1.77 & 709 & 0.40 & $51,106$. & $15,864$. & $215,751$. \\
9 & 71 & 82 & & 66 & 99 & 40 & 76 \\
\hline 201 & 4.06 & 1.80 & 367. & 0.40 & $42,151$. & $10,043$. & $152,097$. \\
0 & 48 & 75 & 5 & 39 & 98 & 38 & 09 \\
\hline 201 & 3.92 & 1.80 & 332 & 0.39 & $33,956$. & $20,143$. & $105,413$. \\
1 & 42 & 58 & & 65 & 57 & 00 & 75 \\
\hline 201 & 4.31 & 1.87 & 539. & 0.37 & $32,881$. & $37,366$. & $145,052$. \\
2 & 9 & 58 & 6 & 69 & 06 & 00 & 57 \\
\hline
\end{tabular}

Let the data in Table III and Table IV be standardized and put it into (1), and the outputs are the degrees of order of insurance innovation and financial development subsystems' order parameters, which are listed in Table V and Table VI.

TABLE V. DEGREE OF ORDER OF INSURANCE INNOVATION SUBSYSTEM'S ORDER PARAMETERS

\begin{tabular}{|c|c|c|c|c|c|c|c|c|}
\hline $\begin{array}{c}\text { Ye } \\
\text { ar }\end{array}$ & e11 & e12 & e13 & e14 & e15 & e16 & e17 & e18 \\
\hline 200 & 0.07 & 0.89 & 0.22 & 0.06 & 0.63 & 0.00 & 0.00 & 0.00 \\
5 & 45 & 93 & 48 & 05 & 08 & 00 & 00 & 00 \\
\hline 200 & 0.00 & 0.65 & 0.00 & 0.08 & 0.00 & 0.38 & 0.24 & 0.26 \\
6 & 00 & 85 & 00 & 67 & 00 & 92 & 31 & 92 \\
\hline 200 & 0.03 & 0.00 & 1.00 & 0.00 & 1.00 & 0.22 & 1.00 & 0.57 \\
7 & 04 & 00 & 00 & 00 & 00 & 54 & 00 & 53 \\
\hline 200 & 0.47 & 0.17 & 1.00 & 0.29 & 0.05 & 0.74 & 0.83 & 0.63 \\
8 & 65 & 94 & 00 & 23 & 99 & 89 & 17 & 35 \\
\hline 200 & 0.64 & 0.40 & 0.89 & 0.83 & 0.51 & 0.88 & 0.69 & 0.79 \\
9 & 96 & 62 & 97 & 42 & 92 & 53 & 73 & 25 \\
\hline 201 & 1.00 & 1.00 & 0.48 & 1.00 & 0.13 & 1.00 & 0.52 & 0.81 \\
0 & 00 & 00 & 69 & 00 & 00 & 00 & 63 & 29 \\
\hline 201 & 0.44 & 0.47 & 0.74 & 0.80 & 0.03 & 0.84 & 0.37 & 0.91 \\
1 & 14 & 12 & 24 & 63 & 29 & 26 & 53 & 39 \\
\hline 201 & 0.38 & 0.17 & 0.64 & 0.45 & 0.03 & 0.84 & 0.19 & 1.00 \\
2 & 23 & 11 & 93 & 77 & 69 & 71 & 96 & 00 \\
\hline
\end{tabular}

TABLE VI. DEGREE OF ORDER OF FINANCIAL DEVELOPMENT SUBSYSTEM'S ORDER PARAMETERS

\begin{tabular}{|c|c|c|c|c|c|c|c|}
\hline $\begin{array}{c}\text { Yea } \\
\mathbf{r}\end{array}$ & $\mathbf{e 2 1}$ & $\mathbf{e 2 2}$ & $\mathbf{e 2 3}$ & $\mathbf{e 2 4}$ & $\mathbf{e 2 5}$ & $\mathbf{e 2 6}$ & $\mathbf{e 2 7}$ \\
\hline 200 & 0.000 & 0.282 & 0.484 & 0.000 & 0.000 & 0.000 & 0.000 \\
5 & 0 & 2 & 9 & 0 & 0 & 0 & 0 \\
\hline 200 & 0.556 & 0.233 & 0.000 & 1.000 & 0.214 & 0.053 & 0.069 \\
6 & 6 & 3 & 0 & 0 & 0 & 6 & 0 \\
\hline 200 & 0.896 & 0.013 & 0.292 & 0.989 & 0.669 & 0.085 & 0.221 \\
7 & 9 & 0 & 3 & 0 & 5 & 3 & 1 \\
\hline 200 & 0.538 & 0.000 & 0.598 & 0.998 & 0.393 & 0.180 & 0.567 \\
8 & 6 & 0 & 6 & 5 & 6 & 9 & 5 \\
\hline 200 & 0.902 & 0.731 & 1.000 & 0.988 & 1.000 & 0.391 & 1.000 \\
9 & 0 & 1 & 0 & 3 & 0 & 2 & 0 \\
\hline 201 & 0.908 & 0.811 & 0.207 & 0.981 & 0.798 & 0.226 & 0.653 \\
0 & 4 & 9 & 6 & 3 & 7 & 4 & 0 \\
\hline 201 & 0.857 & 0.807 & 0.125 & 0.962 & 0.614 & 0.512 & 0.398 \\
1 & 8 & 2 & 2 & 6 & 5 & 4 & 6 \\
\hline 201 & 1.000 & 1.000 & 0.606 & 0.912 & 0.590 & 1.000 & 0.614 \\
2 & 0 & 0 & 9 & 6 & 3 & 0 & 6 \\
\hline
\end{tabular}

Put the data of Table V and Table VI into (2), and the outputs are the degrees of order of insurance innovation subsystem and the degree of order of financial development subsystem. Which are listed in Table VII. Let 2005 be initial time, $\delta=0.5$, and put the data of Table $\mathrm{V}$ and Table VI into (3), The output is the synergy degree of insurance innovation and financial development, which is listed and graphed in Table VII and Fig1.

TABLE VII. DEGREE OF ORDER OF SUBSYSTEMS AND

\begin{tabular}{|c|c|c|c|}
\hline Year & $\begin{array}{c}\text { Degree of order of } \\
\text { insurance } \\
\text { innovation } \\
\text { subsystem }\end{array}$ & $\begin{array}{c}\text { Degree of order of } \\
\text { financial } \\
\text { development } \\
\text { subsystem }\end{array}$ & $\begin{array}{c}\text { Synergy } \\
\text { degree of } \\
\text { subsystems }\end{array}$ \\
\hline 2005 & 0.2249 & 0.3699 & - \\
\hline 2006 & 0.2707 & 0.2164 & 0.8185 \\
\hline 2007 & 0.3974 & 0.2374 & 0.6600 \\
\hline 2008 & 0.2723 & 0.4849 & 0.5811 \\
\hline 2009 & 0.6345 & 0.8226 & 0.6178 \\
\hline 2010 & 0.5758 & 0.5622 & 0.8796 \\
\hline 2011 & 0.3331 & 0.5214 & 0.6176 \\
\hline 2012 & 0.2351 & 0.7951 & 0.0599 \\
\hline
\end{tabular}

SYNERGY DEGREE OF SUBSYSTEMS

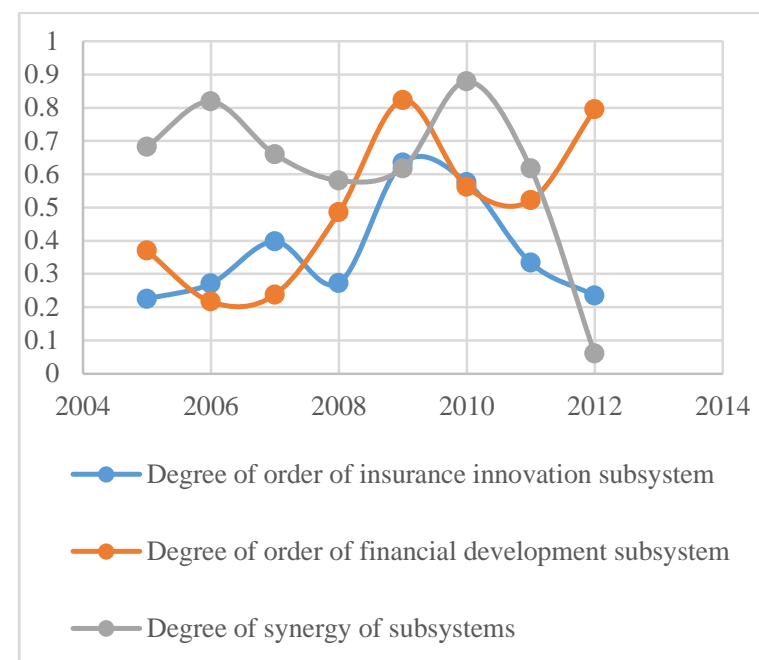

Figure 1.

Degree of Order of Subsystems and Synergy Degree of Subsystems.

Table VII and Fig 1 indicated that the degree of order of insurance innovation subsystem had been rising slowly, and the degree of order of financial development subsystem had been rising in volatility before the 2008 financial crisis. The synergy degree of subsystems was above a relatively high level at that time. The market showed much less interest to new financial derivatives due to the 2008 financial crisis. It drove the degree of order of insurance innovation subsystem down to the lowest. In 2009, governments all over the world began to conduct a comprehensive strong intervention in the financial system. A lot of government capital injections and political interventions were implemented. As a consequence, the degree of order of insurance innovation subsystem and the degree of order of financial development subsystem increased to more than 0.6 and more than 0.8 . The degree of order which is extremely high can't be reached only by the force of market. That is to say the high level of degree of order should thank to the government support largely. But the decrease of the synergy degree of subsystems indicated that although the government intervention 
boosted single market, it could not replace the market force to coordinate the relationship between the insurance innovation and financial development. In 2010, with the gradual quit of government interventions, the degree of order of two subsystems declined slightly. The synergistic descend of the degree of order of two subsystems was not satisfactory, they were at a high level of synergy degree though. The financial development subsystem established growth channel orderly resulting from support of other financial fields, but the degree of order of insurance innovation subsystem decreased year by year. Synergy degree of them reduced greatly. It implicated that the insurance innovation subsystem might not be completely free from the effects of the financial crisis or other antis. The fears of market to new financial derivatives and new financial instruments were not disappear with the leaving of financial crisis. At the same time, it also showed that the insurance innovation of China had entered a bottleneck period and been in the deep waters of reform. The innovation and development of insurance had already couldn't adapt to the pace of financial development. Only by insisting on the reform of insurance innovation, can the government let the insurance industry step on the orderly growth path again.

\section{CONCLUSIONS}

The author used synergy theory to analyze the degree of order of insurance innovation and financial development and the synergistic relationship between them. Conclusion could be made according to the output result that China's financial development was in a steady upward track. The government should maintain the deepening of financial reform trend and increase the support for modern financial service. The insurance innovation slowed continuously after 2009, the degree of order of insurance innovation is now record low, and the synergy degree of insurance innovation and financial development decreased continually. There might be a mutual constraints relationship between them. The government should adjust the operating mechanism of insurance market, encourage insurance innovation and create a synergistic developing environment as soon as possible.

\section{ACKNOWLEDGMENT}

This research was supported by the General Virtual Economy Research Foundation (Grant No. GX20121022(Y)). All support is gratefully acknowledged.

\section{REFERENCES}

[1] Yong'an Lian, Finance and Insurance. Nanjing: Southeast University Press, 2003.

[2] Carvajal, Andrés, Marzena Rostek, and Marek Weretka. "Competition in financial innovation." Econometrica 80.5 (2012), pp.1895-1936.

[3] Outreville, J. Francois. "The economic significance of insurance markets in developing countries." Journal of Risk and Insurance (1990), pp.487-498

[4] Ward, Damian, and Ralf Zurbruegg. "Does insurance promote economic growth? Evidence from OECD countries." Journal of Risk and Insurance (2000), pp.489-506.

[5] Zhichao Xie, and Jiang Du. "An Empirical Analysis on Interaction between Insurance Markets and Finance Development in China." Modern Economic Science 28.3 (2006), pp.54-59.

[6] Kunrong Shen, and Feng Wei. " Research on the non-linear growth effect of Chinese insurance market development." Journal of Financial Research 7 (2010), pp.158-170.

[7] Zhao Jinwen, Xing Tiancai, and Xiong Lei. "The Effect of Insurance Consumption on Economic Growth in China." Economic Research Journal 1 (2010), pp.39-50.

[8] Wu Yonggang, and $\mathrm{Li}$ Zheng." The Effect of Insurance Development on Economic Growth in China : Based on the View of Financial Synergy."Nankai Economic Studies, 2013 (004), pp.82-94

[9] Changqi Tao, And Yawei Qi. "The Synergic Mechanism Between Technology Innovation of Information Industry and Industrial System Growth Based on Convergence." Science of Science and Management of S.\&T., 30.11 (2009), pp.86-93.

[10] Jun Jia, and Zhuo Zhang. "Empirical Study on Synergy Development Between Techonological Innovation and Energy Efficency in China's High-tech Industry." China Population,Resources and Environment, 2013, 23(2), pp.36-42 